\title{
IMPLEMENTASI PENDIDIKAN POLITIK MELALUI KEGIATAN EKSTRA KURIKULER DI SMA NEGERI 1 KECAMATAN BOLAANG UKI KABUPATEN BOLAANG MONGONDOW SELATAN
}

\author{
Ekri Yuwansa Gobel'1, Rasid Yunus ${ }^{2}$, Ramli Mahmud ${ }^{3}$. \\ Fakultas Ilmu Sosial Universitas,Negeri Gorontalo Indonesia \\ (gobelekri@gmail.com) \\ (rasidyunus@ung.ac.id) \\ (ramlimahmud_ram@yahoo.com)
}

\section{Info Artikel}

Sejarah Artikel: Diterima (Mei) (2021) Disetujui (Juni) (2021) Dipublikasikan (Juli) (2021)

\section{Keywords:}

Ekstra Kurikuler Pendidikan Politik

\begin{abstract}
Abstrak
Penelitian ini bertujuan : (1) Untuk mengetahui pendidikan politik di SMA Negeri 1 Kecamatan Bolaang Uki Kabupaten Bolmong-Selatan. (2) Untuk mengetahui faktor apa yang mempengaruhi pendidikan politik di sekolah SMA Negeri 1 Kecamatan Bolaang Uki Kabupaten Bolmong-Selatan. Penalitian ini menggunakan metode pendekatan kualitatif yaitu mendeskripsikan data penelitian dalam bentuk kalimat-kalimat berupa keterangan atau pertanyaan-pertanyaan dari responden sesuai dengan realitas yang ditemukan di lapangan. Hasil dari penelitian menunjukan bahwa pendidikan politik di SMA Negeri 1 Bolaang Uki Kabupaten Bolmong-Selatan dapat dilakukan melalui pembelajaran didalam kelas dan diluar kelas, dalam proses pendidikan politik diluar kelas terdapat dua hal yang dapat dilihat pertama, Iklim sosial di sekolah dan kedua, Kegiatan ekstrakurikuler di sekolah.Berdasarkan hasil penlitian dapat ditarik kesimpulan bahwa : (1) Pendidikan politik dilakukan melalui pembelajaran dalam kelas dan diluar kelas melalui kegiatan ekstrakurikuler. (2) Terdapat dua faktor yang mempengaruhi pendidikan politik di SMA Negeri 1 Bolaang Uki diantaranya a). Faktor Sekolah, permasalahan dominan yang dialami oleh sekolah adalah kurangnya keterlibatan guru dalam pelaksanaan kegiatan diluar kelas, b). Kesadaran Siswa, sebagian besar siswa tidak memiliki kesadaran dalam peran sertanya dalam kegiatan ekstrakurikuler.
\end{abstract}

\footnotetext{
${ }^{1}$ Mahasiswa Universitas Negeri Gorontalo

${ }^{2}$ Dosen Universitas Negeri Gorontalo

${ }^{3}$ Dosen Universitas Negeri Gorontalo
} 


\section{PENDAHULUAN}

Pendidikan politik dapat dipahami sebagai salah satu fungsi politik yang ditunaiakan oleh struktur politik masyarakat untuk memberikan pemahaman kepada masyarakat tentang nilai-nilai, symbol-simbol, keyakinan-keyakinan, pandanganpandangan tentang system politik melalui proses dialog, terbuka, kritis, rasional dan penyadaran.dengan adanya pendidikan politik tersebut diharapkan dapat meningkatkan kesadaran warga Negara untuk berpartisipasi dalam kehidupan bernegara.

Pada dasarnya untuk membentuk warga negara yang demokratis dan bertanggung jawab diperlukan pendidikan yang berkualitas. hal ini tercantum dalam undang-undang system pendidikan nasional No. 20 tahun 2003, pasal 1 (ayat 1) menyatakan bahwa : pendidikan adalah usaha sadar dan terencana untuk mewujudkan suasana belajar dan proses pembelajaran agar siswa secara aktif mengembangkan potensi dirinya untuk memiliki kekuatan spiritual keagamaan, pengendalian diri, kepribadian, kecerdasan, serta keterampilan yang diperlukan dirinya, masyarakat, bangsa dan Negara.

Dalam pasal 3 peraturan menteri pendidikan nasional republik Indonesia nomor 39 tahun 2008 tentang pembinaan kesiswaan, menjelaskan materi pembinaan kesiswaan dalam (poin e) meliputi demokrasi, hak asasi manusia, pendidikan politik, lingkungan hidup, kepekaan dan toleransi sosial, dalam konteks masyarakat plural. dalam aturan tersebut dunia pendidikan harus juga dapat berposisi sebagai penyegaran pandangan, wawasan dan nuansa politik agar generasi muda tidak apatis terhadap persoalan politik. Menurut Hasbullah (2005 : 73) disamping tuntutan penguasaan ilmu pengetahuan dan teknologi (IPTEK) dalam kondisi sekarang dimana pola pikir masyarakat semakin maju dan kritis, baik rakyat maupun pemimpin pemerintah dinegara yang demokratis diperlukan pendidikan kewarganegaraan dan kedewasaan politik bagi setiap warga Negara. Untuk memfasilitasi proses pemahaman dan pembelajaran politik bagi siswa tentu peran sekolah menjadi sangat sentral untuk kemudian mengejawantahkan bagaimana demokrasi itu, sekolah menjadi wadah mengasa daya kritis kemampuan para siswa agar peka terhadap keadaaan sosial dan politik. karena diusia 17 tahun para pelajar ini sudah harus berpartisipasi aktif dalam pengambilan keputusan public sehingga upaya menumbuhkan kesadaran politik harus 
dimulai dari sekolah. Menumbuhkan kesadaran politik pada masa SMA sangat penting agar mereka tidak dapat mendapat konsep yang salah dan keliru tentang politik, pendidikan politik ini pada masa remaja sangat menentukan tingginya tingkat kesadaran politik seseorang. semakin awal seorang individu mendapatkan pembelajaran tentang politik maka semakin tumbuh kesadarannya untuk mau ikut berpartisipasi langsung dalam proses demokrasi. Dalam usia 15-17 tahun para siswa ini merupakan usia yang sangat labil dan sangat menentukan arah proses pendidikan seorang individu mereka akan mencoba menyerap berbagai konsep keilmuan dan langsung mengaplikasikannya, pada usia ini menanamkan konsep dan hal-hal yang baru termasuk juga didalamnya mengenai konsep politik, agar kelak mereka tidak buta dan menjadi sasaran pembodohan politik.

Dalam mata pelajaran PKN salah satu materinya mengajarkan pendidikan politik yang kemudian guru PKN sebagai actor sosialisasi politik di sekolah yang berkewajiban untuk memberikan pendidikan politik yang rasional, cerdas, dan santun kepada peserta didik. Guru PKN tentu akan menentukan keberhasilan dari pendidikan plotik di sekolah, tetapi guru PKN justru kewalahan dalam mewujudkan proses demokrasi dan terkesan tidak maksimal dalam menumbuhkan kesadaran politik para peserta didik. Selain itu juga dalam upaya menciptakan karakter kepemimpinan, sekolah dalam hal ini melalui wakil kepala sekolah bidang kemahasiswaan (wakasek) kesiswaan membuat program lewat organisasi siswa (OSIS) yaitu kegiatan latihan dasar kepemimpinan (LDK), tetapi karena kurangnya sosialisasi mengakibatkan para peserta didik tidak memahami untuk apa kegiatan itu dibuat, mereka enggan mengikuti kegiatan ini karena dianggap hanya perploncoan senioritas dan para peserta didik tidak mau lagi terlibat masuk dalam anggota organisasi siswa (OSIS).

\section{METODE PENELITIAN}

Penelitian ini menggunakan metode pendekatan kualitatif yaitu mendeskripsikan data penelitian dalam bentuk kalimat-kalimat berupa Keterangan atau pertanyaan-pertanyaan dari responden sesuai dengan realitas yang ditemukan di lapangan dengan demikian pendekatan yang digunakan lebih berorientasi pada bagaimana pendidikan politik yang ada disekolah tersebut dan faktor - faktor apa saja yang mempengaruhinya kemudian data diteliti dan analisis hasil penelitian yang 
diperoleh melalui metode di atas dianalisis secara kualitatif untuk kemudian disajikan dalam suatu skripsi.

Metode penelitian kualitatif sering disebut metode penelitian naturalistik karena penelitiannya dilakukan pada kondisi yang alamiah disebut juga sebagai metode etnografi penelitian kualitatif dilakukan pada objek alamiah yang berkembang apa adanya dimanipulasi oleh peneliti dan kehadiran peneliti tidak begitu mempengaruhi dinamika pada objek tersebut. Penelitian kualitatif instrumennya adalah peneliti sendiri titik menjadi instrumen, maka peneliti harus memiliki bekal teori dan wawasan luas, sehingga mampu bertanya menganalisis memotret dan menginstruksikan situasi sosial yang diteliti menjadi lebih jelas dan bermakna Penelitian ini merupakan penelitian deskriptif kualitatif.

\section{HASIL PENELITIAN}

Gambaran umum dari lokasi penelitian di SMA Negeri 1 Bolaang Uki yang berada tepat di Desa Molibagu, Kecamatan Bolaang Uki, Kabupaten Bolaang Mongondow Selatan. Adapun SK pendirian pada tanggal 30-05-1991 dengan nomor SK pendirian Sekolah 0283/0/1991. Guru di SMA Negeri 1 Bolaang Uki seluruhnya berjumlah 32 orang di antaranya guru PNS laki-laki berjumlah 3 orang dan perempuan 11 orang, sedangkan guru non PNS laki-laki berjumlah 8 orang dan guru non PNS perempuan berjumlah 7 orang. Selanjutnya tenaga administrasi sekolah seluruhnya berjumlah 3 orang di antaranya PNS perempuan berjumlah 1 orang, sedangkan tenaga administrasi non PNS laki-laki 1 Orang dan non PNS perempuan berjumlah 1 orang. Sedangkan keseluruhan peserta didik di sekolah ini berjumlah 554 orang di antaranya perempuan 290 dan laki-laki 264. Peserta didik kelas X berjumlah 205 orang, perempuan 108 dan laki-laki 97. Peserta didik kelas XI berjumlah 192 orang, perempuan 88 dan laki-laki 104.Peserta didik kelas XII berjumlah 157 orang, perempuan 94 dan laki-laki 63 . Adapun prasarana sebagai faktor yang sangat penting dalam lembaga pendidikan disekolah, apakah sudah memadai atau perlu ditambah dan perbaikan. Sekolah yang memilikiprasarana yang baik dan lengkap akan menarik perhatian dari masyarakat ataupunorang tua anak didik untuk menyekolahkan anak-anak mereka disekolah tersebut.

\section{Pendidikan Politik di Luar kelas}


Seperti kita ketuhui Pendidikan merupakan usaha sadar untuk mengembangkan pengetahuan, kemampuan dan kepribadian subyek didik.Dalam jangka pendek, pendidikan berarti proses belajar mengajar di kelas; dalam jangka menengah pendidikan berarti pengembangan subyek didik seutuhnya; dan dalam jangka panjang pendidikan merupakan fenomena kebudayaan yang menyangkut nilai-nilai moral, estetis dan budaya.Atas hal tersebut pendidikan politik disekolah khususnya di SMA 1 Bolaang Uki untuk pembelajaran di luar kelas adalah melalui kegiatan ekstrakurikuler yakni Osis dan Pramuka.

Sekolah layaknya sejak dini memberikaan muatan pengalaman pendidikan politik kepada siswanya dapat melalui berbagai cara. Hal ini didukung oleh apa yang dikemukakan oleh Dewey (Thomas: 2009) menyatakan bahwa menciptakan miniatur aktivitas demokrasi di ruang kelas sekolah umum saat ini masih menjadi hal yang dihindari. Apabila anak-anak diberikan kesempatan untuk mengalami aktivitas demokrasi di kehidupan sehari- harinya seperti sekolah dengan memberikan tanggung jawab, memberikan informasi untuk membentuk prespektif pribadi, dan diberikan kewenangan untuk mengatur efektivitas kelompoknya sendiri seperti kelas, maka mereka akan dapat menjadi kader pelaku demokrasi untuk satu sama lain. Situasi yang seperti ini jarang ditemukan di sekolah-sekolah dasar sekarang.

\section{Faktor Yang Mempengarui Kurang Efektifnya Pedidikan Politik}

Seperti kita ketahui sosialisasi politik adalah proses di mana seseorang belajar tentang politik dan mengembangkan orientasi pada politik. Proses tersebut hakikatnya merupakan upaya mempelajari nilai-nilai atau budaya politik masyarakat. Sosialisasi politik pada dasarnya adalah proses belajar, baik dari pengalaman maupun pola-pola tindakan. Sosialisasi politikmemberikan indikasi umum hasil belajar tingkahlaku politik dan kelompok berkenaan dengan pengetahuan, nilai-nilai, dan sikap-sikap politik tertentu. Proses sosialisasi politik ialah proses pembentukan sikap dan orientasi politik para anggota masyarakat. Melalui proses sosialisasi politik inilah para anggota masyarakat memperoleh sikap dan orientasi terhadap kehidupan politik yang berlangsung dalam masyarakat. Gabriel A. Almond menjelaskan proses sosialisasi yaitu proses "pengajaran" nilai-nilai masyarakat, dalam hal ini nilai-nilai dan kebuadayaan politik kepada warganegara. Ada dua hal yang penting dan menarik mengenai proses ini, pertama, sosialisasi politik bisa langsung 
melalui pendidikan, dan yang kedua adalah melalui proses tidak langsung yang disebabkan latar belakang kehidupan seseorang. Namun demikian sesuai dengan hasil penelitian terdapat dua faktor yang mempengaruhi pendidikan politik di SMA 1 Bolaang Uki, diantaranya adalah :

\section{Peran Sekolah}

Peranan sekolah kejuruan sebagai salah satu lembaga pendidikan adalah mengembangkan potensi yang dimiliki oleh siswa agar mampu menghadapi tantangan pembangunan.Secara umum tingkat kecerdasan, kemampuan dan keterampilan setiap siswa mempunyai perbedaan yang menyebabkan prestasi belajar setiap siswa berbeda.Kualitas pendidikan siswa dapat dilihat melalui prestasi belajar, karena prestasi belajar tersebut menunjukan sejauh mana tingkat penguasaan siswa terhadap semua mata pelajaran yang ditempuh.

Atas patokan tersebut, dan dikaitkan dengan hasil penelitian dapat digaris bawahi bahwa, dalam menjalankan amanah UU N0 Tahun 2003 tentang sistem pendidikan nasional, lembaga pendidikan yakni sekolah SMA 1 Bolaang Uki belum maksimal. Unsur dalam lingkungan sekolah tentunya ada perangat kepemimpinan kepala sekolah, guru, siswa serta komponen yang terlibat didalamnya.Kendala dihadaoi sekolah dalam kegiatan ekstrakurikuler khususnya Osis dan Pramuka adalah kurang berperannya semua unsur dalam menyukseskan kegiatan tersebut .Sementara dilain sisi, keberhasilan pembelajaran baik didalam kelas dan lebih khusus diluar kelas sangat membutuhkan peran dari semua unsure sekolah. Hal ini berdampak pada keterlibatan siswa dalam membenah dan menggali potensi yang mereka miliki.Kurangnya peran dari sekolah tersebut membuat kegiata ekstrakurikuler di SMA 1 Bolanguki mengalami kendala dan berjalan tidak efektif.

\section{Kesadaran Siswa}

Lingkungan sekolah kedudukannya sangat penting sekali bagi dunia pendidikan atau sekolah, karena satu sama lain saling berhubungan dan saling membutuhkan "secara umum hubungan sekolah dan masyarakat memiliki tujuan yang hendak dicapai yakni peningkatan mutu pendidikan, sehingga pada gilirannya siswa akan merasakan dampak langsung dari kemajuan sekolah tersebut. Demikian pula sebaliknya dari lingkungan yang kurang bagus, kurang mendukung akan berakibat/berpengaruh buruk terhadap perkembangan siswa dan sekolah. 
Penjelasan diatas mencerminkan bahwa lingkungan sekolah sangat potensial dalam membentuk karakter para peserta didik.Hububgannya dengan pendidikan politik bagi siswa, faktor sekolah dan kesadaran bagi saiwa merupakan faktor kunci. Sekolah merupakan tempat belajar bagi siswa, dilingkungan ini, siswa diberikan pengetahuan untuk bekal masa depan bangsa. Seiring dengan hal tersebut, Slameto(2003: 3-5) mengatakan bahwa belajar merupakan suatu perubahan tingkah laku. Ciri-ciri perubahan tingkah laku tersebut adalah sebagai berikut: a) Perubahan terjadi secara sadar Ini berarti seseorang yang belajar akan menyadari terjadinya perubahan itu atau sekurang-kurangnya ia merasakan telah terjadi adanya suatu perubahan pada dirinya. b) Perubahan dalam belajar bersifat kontinu dan fungsional Sebagai hasil belajar, perubahan yang terjadi dalam diri seseorang berlangsung secara berkesinambungan, tidak statis. Satu perubahan yang terjadi akan menyebabkan perubahan berikutnya dan akan berguna bagi kehidupan ataupun proses belajar berikutnya. c) Perubahan dalam belajar bersifat positif dan aktif Dalam perbuatan belajar, perubahan-perubahan itu selalu bertambah dan tertuju untuk memperoleh sesuatu yang lebih baik dari sebelumnya.

Sesuai dengan teori tersebut, menurut hemat penulis apa yang dikemukakan tersebut harus ditopang oleh semnagat kolektifitas seluruh elemen atau prangkat dalam dunia pendidikan khususnya sekolah. Semua perubahan yang diinginkan dalam dunia pendidikan tidak akan tercapai jika tidak ada kesadaran kolektif dari semua komponen dalam sekolah. Hubungannuya dengan hal tersebut, kebanyakan siswa tidak aktif dalam kegiatan ekstrakurikuer sebagai representasi dari pendidikan politik karena tidak memiliki kesadaran untuk terlibat dalam proses pengembangan diri khususnya pendidikan politik melalui kegiatan Osis dan Pramuka.

Atas hal tersebut, aspek kesadaran politik bukan hanya meliputi aspek kognitif saja namun juga harus melibatkan aspek afektif dan aspek psikomotor.Oleh karena itu, mata pelajaran Pendidikan Kewarganegaraan dianggap tepat karena secara langsung mampu memberikan fasilitas yang lengkap bagi siswa untuk dapat mengembangkan ketiga aspek tersebut dalam memahami berbagai konsep tentang politik.Dengan demikian semakin banyak usaha belajar itu dilakukan maka semakin banyak dan baik perubahan yang diperoleh.Perubahan yang bersifat aktif artinya bahwa perubahan itu tidak terjadi dengan sendirinya melainkan karena usaha sendiri. 


\section{KESIMPULAN}

Berdasarkan pada hasil penelitian dan pembahasan mengenai pendidikan politik di SMA 1 Bolaang Uki di atas, dapat ditarik kesimpulan dalan penelitian ini yakni Pertama, pendidikan politik dilakukan melalui pembelajaran dalam kelas dan diluar kelas melalaui kegiatan ekstralurikuler. Khusus untuk pendidikan politik melalui pembelajaran dalam kelas sudak efektif bila dilihat dari segi kurikulum, ritual kelas dan peran guru. Melalui kurikulum, pendidikan politik lebih khusus pada mata pelajaran PPKn, dimana kurikulum PPKn di SMA lebih fokus pada pembinaan dan sosialiasi politik sebagai wujud pendidikan politik bagi siswa. Sementara melalui ritual kelas, para siswa diajarkan tentang nilai tanggung jawab, disiplin, kesetiakawanan serta menghargai antara sesama dan pendekatan lewat pengalaman yang dialami oleh guru maupun siswa. Disisi lain, semua guru berperan atas pendidikan politik dikelas melalui proses pembelajaran, artiya bukan hanya guru PPKn yang berperan secara aktif namun, semua guru di SMA 1 Bolaang Uki berperan dalam membina siswa dari pembukaan kelas, kegiatan inti pembelajaran hingga menutup kelas.

Kedua, Terdapat dua faktor yang mempengaruhi pendidikan politik di SMA 1 Bolaang Uki diantaranya a) Faktor Sekolah, permsalahan dominan yang dialami oleh sekolah adalah kurangnya keterlibatan guru dalam pelaksanaan kegiatan pembelajaran diluar kelas atau kegiatan ekstrakurikuler melalui Osis dan Pramuka, hal lain yang mempengaruhi peran sekolah adalah keterbatasan fasilitas dan sarana prasarana serta sumber anggaran. b) Kesadaran siswa, sebagian besar siswa tidak memiliki kesadaran dalam peran sertanya dalam kegiatan ekstrakurikuler. Siswa terlibat dalam kegiatan ekstrakurikuler sesuai denagn momentum tahunan seperti pemilihan Ketua Osisi, selebihnya kegiatan kesiswaan di SMA Negeri 1 Bolaang Uki mengalami kemandekan.

\section{DAFTAR PUSTAKA}

Abdur Rahman Assegaf. 2007. Pendidikan Islam di Indonesia. Yogyakarta: Suka Press.

Almond, Gabriel A. dan Verba, Sidney.1990. Budaya Politik, Tingkah Laku Politik danDemokrasi di Lima Negara. Bina Aksara. Jakarta.

Afan Gaffar, 2006. Politik indoneisa: transisi menuju demokrasi.yogyakarta. Pustaka belajar. 
Asmika Rahman, Suharno. 2019. Pelaksanaan Pendidikan Politik Melalui Pembelajaran Pendidikan Pancasila Dan Kewarganegaraan Untuk Meningkatkan Kesadaran Politik Siswa. Jurnal Ilmiah Pendidikan Pancasila Dan Kewarganegaraan. Vol 4, No 2, Hal 282-290. Program Studi Magister PPKN. Universitas Negeri Yogyakarta.

Abdul Rahmat Latif .2019. Partisipasi Politik Pemilih Pemula Di Kecamatan Lemito Kabupaten Pohuwato. Skripsi Jurusan Ilmu Hukum Dan Keamasyarakatan. Fakultas Ilmu Sosial. Universitas Negeri Gorontalo.

Cholisin. 2000. Materi Pokok Ilmu Kewarganegaraan-Pendidikan Kewarganegaraan. UNY.Yogyakarta.

2004. Diktat Pendidikan Kewarganegaraan (Civic Education).Yogyakarta.

..2004.Perspektif Pendidikan Pancasila dan Kewarganegaraan.Kaifa. Bandung.

Kartono, Kartini. 2009. Pendidikan Politik Sebagai Bagian dari Pendidikan Orang Dewasa. Bandung : CV Mandar Maju

Hary Hamersma. 1983. Tokoh-Tokoh Filsafat Barat Modern. Jakarta: Gramedia.

Nasiwan, 2004. "Pendidikan Politik Bagi Para Pemilih Menyongsong Pemilu 2004," Informasi, Kajian Masalah Pendidikan dan Ilmu Sosial, Vol.2 No. I Oktober Tahun 2004. (online)

Nurani Soyomukti, Teori-Teori Pendidikan (Tradisional, (Neo) Liberal, Marxis Sosialis, Postmodern), Yogyakarta: Ar-Ruzz Media. hlm. 155-486

Miriam Budiardjo 2008. Dasar- dasar ilmu politik. Jakarta. Gramedia pustaka

Putri Pratiwi. 2015. Peran Sekolah Dalam Sosialisasi Politik Siswa Di Sma Negeri 1 Purwodadi. Jurusan Ilmu Pemerintahan Fakultas Ilmu sosial dan Ilmu Politik. Universitas Diponegoro

Patilima, Hamid. 2007. Metode penelitian kualitatif. Bandung. Alfabeta

Ramlan Surbakti, 1999. Memahami Ilmu Polilik, Jakarta: PT Gramedia 2007.Memahami Ilmu Politik. Jakarta:PT Gramedia

Rusadi Kantaprawira, 1992. Sistem Politik Indonesia Suatu Model Pengantar.Bandung. Sinar Baru Algensindo.

Rahman H.I, 2007. Sistem politik Indonesia.Yogyakarta.Graha ilmu.

Rusadi Kantaprawira. 2006. Sistem Politik Indonsesia. Bandung. Sinar baru algesindo. 
Satmoko, Kharismandari, Peran Partai Politik Dalam Menerapkan Pendidikan Politik Terhadap Pengurus Dan Kader Partai (Studi Pada Dewan Pengurus Wilayah Partai Kebangkitan Bangsa Provinsi Jawa Timur) Kajian Moral dan Kewarganegaraan. Volume 01 Nomor 03 Tahun 2015, Hal 318-329

Suwardi Endaswara. 2012. Filsafat Ilmu: Konsep, Sejarah dan Pengembangan Metode Ilmiah, Yogyakarta: Capas. hlm. 8.

Sunarso, dkk. 2007. Pendidikan Kewarganegaraan Untuk Sd Dan Mi Kelas IV. Sukoharjo: Graham Multi Grafika

Sagala, Syaiful., 2006. Konsep Dan Makna Pembelajaran. Bandung: Alfabeta.

Sunarso.Pendidikan Politik dan Politik Pendidikan. Jurnal Civic ; Volume 4, No.2, Desember 2007.

Slameto.(2003). Belajar dan Faktor-faktor yang mempengaruhinya. Jakarta: Rineka Cipta.

Sugiyono. 2017. Metode penelitian pendidikan.pendekatan kualitatif dan kuantitaif dan R\&D. Bandung. Alfabeta

Sudijono Sastroatmodjo. 1995. Perilaku politik. Semarang: IKIP Press

Tholib Kasan, 2005. Teori dan Apliaksi Administrasi Pendidikan, (Jakarta: Studia Press,

Wildan Nurul Fajar. 2014. Pelaksanaan Pendidikan Politik Di Sekolah Dalam Meningkatkan Kesadaran Politik Siswa. Pendidikan Kwarganegaraan. FKIP Universitas Muhammadiyah Purwokerto

Yohanes Berkhmas Mulyadi. 2018. Pendidikan Politik Melalui Pembelajaran Pendidikan Kewarganegaraan Untuk Meningkatkan Kesadaran Politik Siswa. Jurnal Inspirasi Pendidikan Vol. 9 No. 1 Tahun 2019 | Hal. 33 - 38. STKIP Persada Khatulistiwa Sintang Indonesia.

Eko Handoyo, Lestari, 2017. PENDIDIKAN POLITIK. Yogyakarta : Pohon Cahaya

Karim Suryadi, Affandi. 2016. Modul 1 Teori dan Konsep dalam Konteks Pendidikan Politik. http://repository.ut.ac.id/4009/1/PKNI4423M1.pdffile:///C:/Users/ACER/Downloads/PKNI4423-M1.pdf.Dwonload pada tanggal.... 9 Agustus 2020 